\title{
Effect of Different Planting Time on Vegetative and Flowering on Five Cultivar of Gladiolus (Gladiolus grandiflorus L.)
}

\author{
Rakesh Kumar $^{1 *}$, Devi Singh ${ }^{1}$ and Sunita Kumari ${ }^{2}$ \\ ${ }^{1}$ Department of Horticulture, Sam Higginbottom University of Agriculture, \\ Technology and Sciences, Allahabad, 211007, U.P., India \\ ${ }^{2}$ Department of Horticulture, G.B. Pant University of Agriculture and Technology, \\ Pantnagar, Uttrakhand, 263145, India \\ *Corresponding author
}

\begin{tabular}{|c|c|}
\hline \multicolumn{2}{|r|}{ A B S T R A C T } \\
\hline & \multirow{6}{*}{$\begin{array}{l}\text { The present study investigates that the effect of three date of planting date } 5^{\text {th }} \text { October, } 20^{\text {th }} \\
\text { October, } 5^{\text {th }} \text { November and cultivars Nova Lux, White Prosperity, Rose Supreme, } \\
\text { American Beauty and Big Time Supreme effect on Gladiolus hybrid characters like } \\
\text { minimum days taken to sprouting of corms }(9.65 \text { days), maximum plant height }(77.84 \mathrm{~cm}) \text {, } \\
\text { number of leaves ( } 8.70 \text { per plant) were stimulated under } 5^{\text {th }} \text { November while the characters } \\
\text { minimum days taken to spike emergence }(68.48 \text { days) and basal florets opening ( } 79.04 \\
\text { days) and maximum length of spike }(64.02 \mathrm{~cm}) \text {, number of florets }(13.42) \text { per spike, length } \\
\text { of florets }(11.04) \text {, maximum vase life }\left(8.25 \text { days) were stimulates planting on } 15^{\text {th }} \text { October }\right. \\
\text { but maximum duration of spike under field was stimulates planting date } 5^{\text {th }} \text { October. } \\
\text { Among the varieties earliest corm sprouting }(10.33 \text { days) and highest vase life }(7.87 \text { days) } \\
\text { were recorded in cv. Rose Supreme while the cv. American Beauty having largest plant } \\
\text { height }(84.96 \mathrm{~cm}) \text {, leaves }(9.24 \text { per plant), length of spike }(74.33) \text {, minimum days to basal } \\
\text { florets opening ( } 71.07 \text { days), length of florets }(11.11 \mathrm{~cm}) \text { and maximum vase life of spike } \\
\text { ( } 9.91 \text { days) were recorded but maximum days required to spike emergence in cv. White } \\
\text { Prosperity. Finally concluded that the planting date } 15^{\text {th }} \text { October to } 5^{\text {th }} \text { November gave } \\
\text { better results with respect vegetative and flowering characters. }\end{array}$} \\
\hline & \\
\hline & \\
\hline Article & \\
\hline & \\
\hline & \\
\hline
\end{tabular}

\section{Introduction}

Gladiolus is a flower of glamour and perfection which is known as the queen of bulbous flowers due to its flower spikes with florets of massive form, brilliant colors, attractive shapes, varying size and excellent shelf life. The modern hybrids are botanically known as Gladiolus grandiflorus belonging to the family Iridaceae. Gladiolus is grown as flower bed in gardens and used in floral arrangements for interior decoration as well as making high quality bouquets (Bose et al.,
2003). Gladiolus are grown an area of 9.37 thousand hectare with a production of 707 million spikes in India (NHB, 2013). The major gladiolus growing areas are Kalimpong (West Bengal), New Delhi, Srinagar (Jammu and Kashmir) and Nainital (Uttar Pradesh).

Date of planting plays an important role in regulating growth and quality of gladiolus (Khan et al., 2008.). Vegetative growth and quality of gladiolus is improved by proper 
planting times which also satisfies the consumer's demands (Zubair et al., 2006). The Planting schedule of gladiolus varies because of differences in photoperiods, temperatures and light intensity and relative humidity. Maximum spikes per plant were obtained from April to May plantings while highest number of corms per plant in tuberose was obtained from March and April plantings (Mubhopadhayay and Banker, 1981). Growth and yield of gladiolus, like other plants, depend on proper planting time. Akpinar and Bulut (2011) reported that the planting time $20^{\text {th }}$ June was found to be the most suitable plantation time when considered sprouting and spiking time and White Prosperity is the best varieties. The present study investigated that the best planting time of different gladiolus cultivar under environmental conditions.

\section{Materials and Methods}

The experiment was carried out. during winter season of 2016-17 at the Research Farm of the Department of Horticulture, Allahabad School of Agriculture Sam Higginbottom University of Agriculture Technology and Sciences, Allahabad (UP.).

The experimental material comprised of 5 gladiolus genotypes viz. Nova Lux, White Prosperity, Rose Supreme, American Beauty and Big Time Supreme planted under three different planting times i.e. $5^{\text {th }}$ October, $20^{\text {th }}$ October, $5^{\text {th }}$ November, 2017. The genotypes were sown as Factorial Randomized Block Design (FRBD) with fifteen treatments and three replications. The treatments are Nova Lux $+5^{\text {th }}$ October, Nova Lux $+20^{\text {th }}$ October, Nova Lux $+5^{\text {th }}$ November, White Prosperity $+5^{\text {th }}$ October, White Prosperity $+20^{\text {th }}$ October, White Prosperity $+5^{\text {th }}$ November, Rose Supreme $+5^{\text {th }}$ October, Rose Supreme + $20^{\text {th }}$ October, Rose Supreme $+5^{\text {th }}$ November, American Beauty $+5^{\text {th }}$ October, American Beauty $+20^{\text {th }}$ October, American Beauty $+5^{\text {th }}$
November, Big Time Supreme $+5^{\text {th }}$ October, Big Time supreme $+20^{\text {th }}$ October and Big time supreme $+5^{\text {th }}$ November. Corms were planted at spacing of $30 \times 20 \mathrm{~cm}$ and standard package were followed to raise the crop. For morphological analysis the genotypes were evaluated for days taken to sprouting of corms, plant height, number of leaves, days taken to flowering, spike length, number of florets per spike and floret size.

\section{Results and Discussion}

The experimental data were analyzed statistically. Mean tables are briefed for interpreting the results regarding days taken to sprouting of corms, plant height, number of leaves, days taken to flowering, spike length, number of florets per spike and floret size of Gladiolus grandiflorus.

\section{Days to plant sprouting}

The results show that the genotypes took more time to sprout as the planting time was earlier. The days taken to sprouting of corms ranges from 9.65 to 12.54 days. The minimum time of 9.65 days was recorded in $5^{\text {th }}$ November planting while maximum time of 12.54 days was recorded in $5^{\text {th }}$ October planting. These results are in close conformity with the findings of Saini et al., (1988) in which late sprouting was observed under delayed planting.

The time taken to sprouting of corms by five different genotypes in three environment ranges from 8.50 to 13.80 days. The minimum time was taken by cv. American Beauty 8.50 days under $5^{\text {th }}$ November planting. Cultivar Nova Lux took the maximum time to sprouts 13.80 days under $5^{\text {th }}$ October planting. The sprouting of corms presents significant variation due to genotype and planting time. Rose Supreme was earliest to sprout irrespective of planting dates as compared to other varieties. The variety Rose 
Supreme took minimum time to sprout in $5^{\text {th }}$ November and also $5^{\text {th }}$ October. This indicates that sprouting of corms is affected by prevailing temperature at time of planting. It is pertinent to mention here that during October to November the average temperature ranges between $24.8-19.4{ }^{0} \mathrm{C}$ respectively which was optimum for corm sprouting (Arora and Sandhu, 1987). The results also show that varieties $\mathrm{CPG}$ and Punjab Flame were comparatively late under all plantings, which might be due to individual genetic makeup of the varieties. These results justify the findings of Sidhu (1989) in gladiolus, Tamberg and Chirva (1980) in gladiolus and Kabacaoğlu (1988) in gladiolus.

\section{Plant height}

The mean values regarding plant height reveals that different planting dates significantly affected plant height given in table 1 . The mean values of different planting dates, maximum plant height was observed in cormels planted on $5^{\text {th }}$ November $77.84 \mathrm{~cm}$, traced by $20^{\text {th }}$ October plantation $77.17 \mathrm{~cm}$, while minimum plant height was observed in those planted on $5^{\text {th }}$ October $74.41 \mathrm{~cm}$. Maximum plant height was observed in cv. American Beauty $86.16 \mathrm{~cm}$ under $5^{\text {th }}$ October planting and minimum plant height was observed in cv. White Prosperity $65.20 \mathrm{~cm}$ under first planting. Regarding the maximum plant height on $5^{\text {th }}$ November might be the result of ideal condition for photosynthesis is through which the plants acquired well developed structure and height. Almost similar results Khan et al., (2008) also stated that, planting time significantly influenced the vegetative growth of Tulip.

\section{Number of leaves}

The mean values regarding number of leaves plant per plant are given in table 1. Various planting dates significantly affected number of leaves plant per plant. Maximum number of leaves was observed in cv. Big Time Supreme (9.26) on $5^{\text {th }}$ October planting. While minimum number of leaves was observed in cv. White Prosperity (8.13) on 5th November planting date. The mean values of different planting dates showed that maximum number 8.78 leaves per plant were produced by corms planted on $20^{\text {th }}$ October, traced by plantation done on $5^{\text {th }}$ November (8.43), while minimum number 8.32 leaves per plant were observed in corms planted on $5^{\text {th }}$ November. The similar finding, maximum number of leaves plant per plant on 20 October was due to the plants has maximum efficiency for development in ideal environmental condition. Ko et al., (1994) also found that earlier planting produced the well-developed plants of gladiolus.

\section{Flowering parameters}

\section{Days taken to spike emergence (days)}

The present study indicates that in $20^{\text {th }}$ October planting, cv. White Prosperity took the minimum time to spike emergence $(62.70$ days) while in maximum time to spike emergence $(87.30$ days $)$ on planting $5^{\text {th }}$ October. The mean values of different planting dates showed that minimum days of spike emergence under $20^{\text {th }}$ October planting date (68.48 days) followed $5^{\text {th }}$ November (74.12 days) and maximum days of spike emergence under $5^{\text {th }}$ October (75.68 days). Among five verities Big Time Supreme had taken maximum days of spike emergence (79.30 days) and minimum days of spike emergence taken cv. White Prosperity?

\section{Days to first flowering opening (days)}

The present study indicates that in $5^{\text {th }}$ October planting, cv. American Beauty took the minimum time to flowering opening (62.70 days) while in maximum time to flower opening (95.80 days) under planting $5^{\text {th }}$ October (Table 2). 
Table.1 Effect of different planting date on different cultivar on vegetative parameters of gladiolus on days taken sprouting of corms, planting height $(\mathrm{cm})$ and total number of leaves (number)

\begin{tabular}{|c|c|c|c|c|c|c|c|c|c|c|c|c|}
\hline \multicolumn{5}{|c|}{ Days taken sprouting of corms } & \multirow{2}{*}{\multicolumn{3}{|c|}{$\begin{array}{c}\text { Plant height }(\mathrm{cm}) \\
\text { Different planting date (D) }\end{array}$}} & \multicolumn{5}{|c|}{ Total no of leaves } \\
\hline \multirow[b]{2}{*}{$\begin{array}{c}\text { Varieties } \\
\text { (V) }\end{array}$} & \multicolumn{3}{|c|}{ Different planting date (D) } & \multirow[b]{2}{*}{$\begin{array}{c}\text { Mean } \\
(\mathbf{V})\end{array}$} & & & & \multirow[b]{2}{*}{$\begin{array}{c}\text { Mean } \\
(\mathbf{V})\end{array}$} & \multicolumn{3}{|c|}{ Different planting date (D) } & \multirow[b]{2}{*}{$\begin{array}{c}\text { Mean } \\
(V)\end{array}$} \\
\hline & $\begin{array}{l}5^{\text {th }} \\
\text { October }\end{array}$ & $\begin{array}{l}15^{\text {th }} \\
\text { October }\end{array}$ & $\begin{array}{c}5^{\text {th }} \\
\text { November }\end{array}$ & & $\begin{array}{l}5^{\text {th }} \\
\text { October }\end{array}$ & $\begin{array}{l}15^{\text {th }} \\
\text { October }\end{array}$ & $\begin{array}{c}5^{\text {th }} \\
\text { November }\end{array}$ & & $\begin{array}{l}5^{\text {th }} \\
\text { October }\end{array}$ & $\begin{array}{l}15^{\text {th }} \\
\text { October }\end{array}$ & $\begin{array}{c}5^{\text {th }} \\
\text { November }\end{array}$ & \\
\hline $\mathrm{V}_{1}$ & 13.80 & 10.43 & 10.66 & 11.63 & 69.26 & 72.26 & 72.66 & 71.40 & 7.30 & 8.50 & 8.23 & 8.01 \\
\hline $\mathrm{V}_{2}$ & 12.66 & 10.36 & 10.16 & 11.06 & 65.20 & 68.46 & 67.86 & 67.17 & 8.30 & 8.43 & 8.13 & 8.28 \\
\hline $\mathrm{V}_{3}$ & 12.13 & 9.36 & 9.50 & 10.33 & 68.20 & 76.50 & 82.10 & 75.60 & 8.30 & 8.50 & 8.16 & 8.32 \\
\hline $\mathrm{V}_{4}$ & 11.46 & 10.20 & 8.50 & 10.56 & 86.16 & 85.20 & 84.96 & 85.44 & 8.46 & 9.80 & 9.46 & 9.24 \\
\hline $\mathrm{V}_{5}$ & 12.63 & 9.30 & 9.43 & 10.45 & 83.23 & 83.46 & 81.63 & 82.77 & 9.26 & 8.66 & 8.16 & 8.70 \\
\hline Mean (D) & 12.54 & 9.93 & 9.65 & & 74.41 & 77.17 & 77.84 & & 8.32 & 8.78 & 8.43 & \\
\hline \multicolumn{5}{|c|}{$\begin{array}{l}\text { C.D. at } 5 \% \\
\text { Varieties }-0.47 \\
\text { Planting Date }-0.36 \\
\text { Interaction (V X D) - } 0.82\end{array}$} & \multicolumn{4}{|c|}{$\begin{array}{l}\text { C.D. at 5\% } \\
\text { Varieties }-3.23 \\
\text { Planting Date -2.50 } \\
\text { Interaction (V X D) - } 5.59\end{array}$} & \multicolumn{4}{|c|}{$\begin{array}{l}\text { C.D. at } 5 \% \\
\text { Varieties }-0.26 \\
\text { Planting Date }-0.20 \\
\text { Interaction (V X D) - } 0.46\end{array}$} \\
\hline
\end{tabular}

Table.2 Effect of different planting date on different cultivars on flowering parameters of gladiolus on days taken to spike emergence, days taken to basal floret opening and length of spike $(\mathrm{cm})$

\begin{tabular}{|c|c|c|c|c|c|c|c|c|c|c|c|c|}
\hline \multicolumn{5}{|c|}{ Days taken to spike emergence } & \multirow{2}{*}{\multicolumn{3}{|c|}{$\begin{array}{c}\text { Days taken to basal floret opening } \\
\text { Different planting date (D) }\end{array}$}} & \multicolumn{5}{|c|}{ Length of spike(cm) } \\
\hline \multirow[b]{2}{*}{$\begin{array}{c}\text { Varieties } \\
\text { (V) }\end{array}$} & \multicolumn{3}{|c|}{ Different planting date (D) } & \multirow[b]{2}{*}{$\begin{array}{l}\text { Mean } \\
(\mathrm{V})\end{array}$} & & & & \multirow[b]{2}{*}{$\begin{array}{l}\text { Mean } \\
(\mathbf{V})\end{array}$} & \multicolumn{3}{|c|}{ Different planting date (D) } & \multirow[b]{2}{*}{$\begin{array}{c}\text { Mean } \\
(V)\end{array}$} \\
\hline & $\begin{array}{l}5^{\text {th }} \\
\text { October }\end{array}$ & $\begin{array}{l}15^{\text {th }} \\
\text { October }\end{array}$ & $\begin{array}{c}5^{\text {th }} \\
\text { November }\end{array}$ & & $\begin{array}{l}5^{\text {th }} \\
\text { October }\end{array}$ & $\begin{array}{l}15^{\text {th }} \\
\text { October }\end{array}$ & $\begin{array}{c}5^{\text {th }} \\
\text { November }\end{array}$ & & $\begin{array}{l}5^{\text {th }} \\
\text { October }\end{array}$ & $\begin{array}{l}15^{\text {th }} \\
\text { October }\end{array}$ & $\begin{array}{c}5^{\text {th }} \\
\text { November }\end{array}$ & \\
\hline $\mathrm{V}_{1}$ & 87.30 & 72.00 & 72.80 & 77.36 & 95.80 & 87.70 & 91.33 & 91.61 & 52.83 & 61.23 & 50.86 & 54.97 \\
\hline $\mathrm{V}_{2}$ & 62.33 & 62.70 & 73.50 & 66.17 & 80.66 & 73.00 & 81.96 & 78.54 & 71.73 & 74.43 & 72.30 & 72.82 \\
\hline $\mathrm{V}_{3}$ & 71.70 & 71.30 & 72.00 & 71.66 & 84.13 & 82.73 & 85.96 & 84.27 & 41.66 & 41.03 & 40.30 & 41.00 \\
\hline $\mathrm{V}_{4}$ & 80.00 & 63.06 & 71.83 & 71.63 & 69.26 & 70.93 & 73.03 & 71.07 & 74.76 & 75.36 & 72.93 & 74.35 \\
\hline $\mathrm{V}_{5}$ & 77.06 & 73.36 & 85.46 & 78.63 & 83.26 & 80.83 & 80.66 & 81.58 & 68.26 & 68.06 & 67.21 & 67.84 \\
\hline Mean (D) & 75.68 & 68.48 & 75.12 & & 82.62 & 79.04 & 82.59 & & 61.85 & 64.02 & 60.72 & \\
\hline \multicolumn{5}{|c|}{$\begin{array}{l}\text { C.D. at } 5 \% \\
\text { Varieties }-3.58 \\
\text { Planting Date }-2.77 \\
\text { Interaction(V X D) - } 6.21\end{array}$} & \multicolumn{4}{|c|}{$\begin{array}{l}\text { C.D. at } 5 \% \\
\text { Varieties }-1.04 \\
\text { Planting Date }-0.81 \\
\text { Interaction }(\mathrm{V} \text { X D) - } 1.81\end{array}$} & \multicolumn{4}{|c|}{$\begin{array}{l}\text { C.D. at } 5 \% \\
\text { Varieties }-1.16 \\
\text { Planting Date }-0.90 \\
\text { Interaction (V X D) - } 2.01\end{array}$} \\
\hline
\end{tabular}


Table.3 Effect of different planting date on different cultivars on flowering parameters of gladiolus on number of florets per spike, length of florets $(\mathrm{cm})$ and duration of spike under field condition

\begin{tabular}{|c|c|c|c|c|c|c|c|c|c|c|c|c|}
\hline \multicolumn{5}{|c|}{ Number of florets per spike } & \multirow{2}{*}{\multicolumn{3}{|c|}{$\begin{array}{c}\text { Length of florets (cm) } \\
\text { Different planting date (D) }\end{array}$}} & \multicolumn{5}{|c|}{ Duration of spike under field condition (days) } \\
\hline \multirow[b]{2}{*}{$\begin{array}{c}\text { Varieties } \\
\text { (V) }\end{array}$} & \multicolumn{3}{|c|}{ Different planting date (D) } & \multirow[b]{2}{*}{$\begin{array}{c}\text { Mean } \\
(\mathrm{V})\end{array}$} & & & & \multirow[b]{2}{*}{$\begin{array}{c}\text { Mean } \\
(\mathbf{V})\end{array}$} & \multicolumn{3}{|c|}{ Different planting date (D) } & \multirow[b]{2}{*}{$\begin{array}{c}\text { Mean } \\
(\mathrm{V})\end{array}$} \\
\hline & $\begin{array}{c}5^{\text {th }} \\
\text { October }\end{array}$ & $\begin{array}{c}15^{\text {th }} \\
\text { October }\end{array}$ & $\begin{array}{c}5^{\text {th }} \\
\text { November }\end{array}$ & & $\begin{array}{c}5^{\text {th }} \\
\text { October }\end{array}$ & $\begin{array}{c}15^{\text {th }} \\
\text { October }\end{array}$ & $\begin{array}{c}5^{\text {th }} \\
\text { November }\end{array}$ & & $\begin{array}{c}5^{\text {th }} \\
\text { October }\end{array}$ & $\begin{array}{c}15^{\text {th }} \\
\text { October }\end{array}$ & $\begin{array}{c}5^{\text {th }} \\
\text { November }\end{array}$ & \\
\hline $\mathrm{V}_{1}$ & 15.53 & 14.54 & 13.20 & 14.42 & 10.30 & 10.86 & 10.48 & 10.55 & 9.53 & 9.60 & 9.88 & 9.67 \\
\hline $\mathrm{V}_{2}$ & 13.23 & 15.36 & 13.68 & 14.09 & 10.46 & 10.53 & 10.20 & 10.40 & 11.08 & 11.11 & 10.91 & 11.03 \\
\hline $\mathrm{V}_{3}$ & 10.56 & 10.44 & 9.86 & 10.29 & 10.50 & 10.60 & 10.50 & 10.53 & 8.14 & 8.15 & 8.07 & 8.12 \\
\hline $\mathrm{V}_{4}$ & 14.16 & 14.63 & 13.52 & 14.10 & 11.30 & 11.56 & 11.66 & 11.51 & 10.26 & 9.28 & 10.18 & 9.91 \\
\hline $\mathrm{V}_{5}$ & 11.73 & 12.13 & 10.25 & 11.37 & 11.66 & 11.66 & 11.11 & 11.48 & 7.88 & 7.75 & 7.83 & 7.82 \\
\hline Mean (D) & 13.04 & 13.42 & 12.10 & & 10.84 & 11.04 & 10.79 & & 9.38 & 9.18 & 9.37 & \\
\hline \multicolumn{5}{|c|}{$\begin{array}{l}\text { C.D. at } 5 \% \\
\text { Varieties }-0.41 \\
\text { Planting Date }-0.32 \\
\text { Interaction (V X D) }\end{array}$} & \multicolumn{4}{|c|}{$\begin{array}{l}\text { C.D. at } 5 \% \\
\text { Varieties }-0.20 \\
\text { Planting Date }-0.15 \\
\text { Interaction (V X D) }-0.25\end{array}$} & \multicolumn{4}{|c|}{$\begin{array}{l}\text { C.D. at } 5 \% \\
\text { Varieties }-0.18 \\
\text { Planting Date }-0.14 \\
\text { Interaction }(V \text { X D) }-0.31\end{array}$} \\
\hline
\end{tabular}

Table.4 Effect of different planting date on different cultivars on flowering parameters of gladiolus on vase life of spike

\begin{tabular}{|c|c|c|c|c|}
\hline \multicolumn{5}{|c|}{ Vase life of spike (days) } \\
\hline \multirow{2}{*}{ Varieties (V) } & \multicolumn{3}{|c|}{ Different planting date (D) } & \multirow{2}{*}{ Mean $(\mathbf{V})$} \\
\hline & $5^{\text {th }}$ October & $15^{\text {th }}$ October & $5^{\text {th }}$ November & \\
\hline $\mathrm{V}_{1}$ & 8.23 & 8.25 & 8.36 & 8.28 \\
\hline $\mathrm{V}_{2}$ & 8.40 & 8.63 & 8.83 & 8.62 \\
\hline $\mathrm{V}_{3}$ & 7.85 & 7.90 & 7.86 & 7.87 \\
\hline $\mathrm{V}_{4}$ & 8.08 & 8.55 & 8.03 & 8.22 \\
\hline $\mathrm{V}_{5}$ & 7.73 & 7.93 & 7.36 & 7.67 \\
\hline Mean (D) & 8.06 & 8.25 & 8.09 & \\
\hline \multicolumn{5}{|c|}{$\begin{array}{l}\text { C.D. at } 5 \% \\
\text { Varieties }-0.17 \\
\text { Planting Date }-0.13 \\
\text { Interaction (V X D) }\end{array}$} \\
\hline
\end{tabular}


The days take to flower opening ranges from 69.26 to 95.80 days in five gladiolus genotypes. The mean values of different planting dates showed that minimum days of first flower opening under $20^{\text {th }}$ October planting date (79.40) followed $5^{\text {th }}$ November (82.59) and maximum days of flower opening under $5^{\text {th }}$ October (82.62). Among five verities Nova Lux had taken maximum days of first flower opening (91.61) and minimum days of first flower opening taken cv. American Beauty (71.07). The earliest flowering was reported in $20^{\text {th }}$ October planting which took 79.04 days followed by $5^{\text {th }}$ November planting. The genotypes took maximum time to flower under 5 October planting (82.62). Dod et al., (1989) reported that under late planting emergence of spike was observed earlier. The earliest flowering was reported in cv. American Beauty (71.07 days) followed by White Prosperity (78.54 days).

\section{Spike length (cm)}

Data embodied in table 1 indicates that there was significant effect of genotypes, environments and genotype environments interaction on spike length. Cultivar Rose Supreme recorded the minimum spike length $(41.00 \mathrm{~cm})$ under all plantings ranging from 40.30 to $75.36 \mathrm{~cm}$. The maximum was recorded in cv. White Prosperity $(72.82 \mathrm{~cm})$. The longest spike was recorded under $20^{\text {th }}$ October planting $(64.02 \mathrm{~cm})$ and the spike length reduced as planting time was delayed. The minimum length was recorded under $5^{\text {th }}$ November planting $(61.85 \mathrm{~cm})$. Nijasure and Ranpise (2005) also reported that planting of gladiolus corms on $15^{\text {th }}$ October was ideal for better flower in terms of spike length. The plant develops better root system and luxuriant growth by quantities of photosynthates under favorable climatic conditions whereas, in late planting, plant establishment and growth is poor due to low temperature in November. However, the present experiment also presents a wide range of variation for spike length among the varieties. Such a wide variation for this character is mainly due to genetic nature confirming the earlier reports in gladiolus (Singh et al., 2000) (Table 3).

\section{Number of florets per spike}

The results show that the cv. Nova Lux produced the maximum number of florets per spike (15.53) on $5^{\text {th }}$ October and minimum number of florets per spike in cv. Rose Supreme (9.86) on $5^{\text {th }}$ November planting. The maximum number of florets per spike was recorded under $20^{\text {th }}$ October planting (13.42) which differs significantly from $5^{\text {th }}$ October planting (13.04). Minimum number of florets per (12.10) was found on $5^{\text {th }}$ November planting. According to Arora and Sandhu (1987) reported that more number of florets per spike in early planting as compare to late planting of corms. Among all five verities cv. Nova Lux (14.42) was observed maximum number of floret per spike and cv. Rose Supreme (10.29) minimum number of florets per spike.

\section{Floret length $(\mathrm{cm})$}

The results indicated that under first planting the maximum floret size was recorded in $\mathrm{cv}$. Big Time Supreme $(11.66 \mathrm{~cm})$. Cultivar Big Time Supreme $(11.66 \mathrm{~cm})$ produced the biggest florets under second planting followed by cv. American Beauty $(11.56 \mathrm{~cm})$. Cultivar American Beauty produced the biggest florets under November planting. The smallest florets were produced by cv. American Beauty under November planting. Among three date of planting on $20^{\text {th }}$ October planting date were recorded maximum sizes of florets $(11.04 \mathrm{~cm})$. While smallest sizes of floret were recorded under earlier planting date on $5^{\text {th }}$ October. Among five genotype of 
gladiolus cultivar cv. American Beauty were recorded biggest size of floret $(11.51 \mathrm{~cm})$ and White Prosperity was observed minimum size of floret $(10.40 \mathrm{~cm})$. This variation of size in different varieties might be due to genetic contribution of varieties under observation.

\section{Vase life (days)}

The maximum vase life of spikes was found more in later planting compare to early plantings. The plants with maximum vase life (8.25 days) were produced when planting was accomplished on $20^{\text {th }}$ October followed by $5^{\text {th }}$ November (8.09 days) while minimum days number of vase life on $5^{\text {th }}$ October (8.06 days) were recorded. Among five cultivars of gladiolus White Prosperity (8.62 days) and minimum number of vase life in cv. Big Time Supreme (7.67days) (Table 4).

Finally, concluded that among five varieties and the three planting dates, $15^{\text {th }}$ October to $5^{\text {th }}$ November proved favorable for vegetative as well as flowering characters. American Beauty, White Prosperity and Nova Lux had the best result in all growth and flowering.

\section{References}

Ahmad, I., Khattak, A.M. and Amin, N. U. 2011. Effect of planting dates on the growth of gladiolus corms in peshawar. Sarhad. J. Agric, 27(2):195-200.

Akpinar, E., and Bulut, Y., 2011. Study on the growth and development of some gladiolus (gladiolus 1.) varieties planted in different time under the ecological conditions of Erzurum. African Journal of Agricultural Research, 6(13):31433148 .

Arora, J.S., and Sandhu, G.S., 1987. Effect of two planting dates on the performance of fifteen gladiolus cultivars. Punjab Horticulture Journal, 27(4): 243 - 249.

Bose, T.K., Yadav, L.P., Pal, P., Das, P. and
Parthasarathy, V.A. 2003. Commercial Flowers. 2 (2): 164-165

Dod, V.N., Sadawarte, K.T., Kulwal, L.V., Vaidya, S.W., 1989. Effect of different dates of planting and size of corm on growth and flower yield of Gladiolus, PKV Research Journal. 13(2): 164-165.

Kabacaoğlu, S., 1988. Research on the effects of yield and quality of some gladiolus varieties growed in different planting time in undercover conditions. E.U. Department of Landscape Architecture, Ms Thesis, Izmir (Tr).

Khan, F.U., Jhon, A.Q., Khan F.A. and Mir, M.M., 2008. Effect of planting time on flowering and bulb production of tulip conditions in Kashmir. Indian Journal of Horticulture, 65(1): 0972-8538.

Ko, J.Y., Kim, S.K., Um, N.Y., Han, J.S., and Lee, K.K., 1994. Planting times and corm grades of Gladiolus gandavensis for retarding culture in high land, $R D A$ Journal of Agriculture Science. 36(1): $430-434$.

Mubhopadhayay, A., and G.J. Banker. 1981. Effect of time of planting on growth, flowering and bulb production in tuberose cv. "single". Indian Institute of Horticulture Research, Bangalore

Nijasure, S.N., Ranpise, S.A., 2005. Effect of date of planting on growth, flowering and spike yield of gladiolus cv. American Beauty under Konkan condition of Maharashtra. Haryana of Journal Horticultural Science, 34(12):73.

Saini, R.S., Gupta, A.K., Yamdagni, R. 1988. Effect of planting time on the flowering and cormel production of gladiolus. South Ind. Hort., 36(5): 248-251.

Sidhu, G.S., 1989. Variability of genotypes of gladiolus due to environments. M.Sc Thesis, Punjab Agricultural University, Ludhiana.

Singh, K., Singh, P. and Arora, J.S., 2000. Effect of cultivar response, season, 
stage of harvest and sucrose on keeping quality of gladiolus spikes. Proceeding of the National Conference on Gladiolus. January, 143-149.

Tamberg, T.G., and Chirva, Z.F., (1980). Effect of climatic conditions on Gladiolus growth and development. Hortic. Abstr, 50(6) (4432), Leningrad, USSR.

Thakur, T., Dhatt, K.K. and Ahmed, S., 2015.
Effect of planting time on growth and flowering of Gladiolus. International Journal of Current Research and Academic Review, 3 (5): 145-152.

Zubair, M., Wazir, F.K., Akhtar, S. and Ayub, G., 2006. Planting dates affect floral characteristics of gladiolus under the soil and climatic conditions of Peshawar. Pakistan Journal of Biological Science, 9(9): 1669-1676.

\section{How to cite this article:}

Rakesh Kumar, Devi Singh and Sunita Kumari. 2017. Effect of Different Planting Time on Vegetative and Flowering on Five Cultivar of Gladiolus (Gladiolus grandiflorus L.). Int.J.Curr.Microbiol.App.Sci. 6(9): 2124-2131. doi: https://doi.org/10.20546/ijcmas.2017.609.261 